\title{
PENGGUNAAN AUGMENTED REALITY PADA SEKOLAH MENENGAH ATAS DI INDONESIA
}

\author{
Reghie Wisnu Pradana \\ Jurusan Teknologi Pendidikan Fakultas Ilmu Pendidikan Universitas Negeri Malang \\ email korespondensi: reghie.wisnupradana.1801216@students.um.ac.id
}

\begin{abstract}
Abstrak: Teknologi augmented reality semakin marak berkembang di era seperti sekarang ini. Penggunaannya dapat membantu berbagai sektor termasuk pendidikan sekolah menengah atas. Teknologi augmented reality pada proses pembelajaran akan sangat membantu siswa dalam memahami suatu materi yang ada. Artikel ini dibuat untuk menelaah penggunaan augmented reality pada Seskolah Menengah Atas yang ada di Indonesia. Adanya artikel ini diharapkan dapat membantu mengetahui seberapa jauh penggunaan teknologi augmented reality pada sekolah menengah atas yang ada di Indonesia.
\end{abstract}

Kata kunci: Pembelajaran, Augmented Reality, Media Pembelajaran

\begin{abstract}
Augmented Reality technology is increasingly widespread in this era. Its use can help various sectors including senior high school education. Augmented Reality Technology in the learning process will greatly help students in understanding an existing material. This article was created to examine the use of Augmented Reality in High Schools in Indonesia. The existence of this article is expected to help find out how far the use of Augmented Reality technology in high schools in Indonesia.
\end{abstract}

Keywords: Learning, Augmented Reality, learning Media 


\section{PENDAHULUAN}

Teknologi

informas

dan

komunikasi pada era ini sudah sangat berkembang pesat. Teknologi digunakan untuk membantu meringankan pekerjaan manusia. Selain itu, teknologi juga merupakan suatu terobosan yang ada dari hal yang belum ada sebelumnya.

Teknologi membantu menciptakan lingkungan belajar yang berkualitas tinggi dengan media yang bervariasi (Saputri, 2017). Pemanfaatan teknologi dalam berbagai sektor sudah sangat berkembang, termasuk dalam sektor pendidikan. Menurut Hidayat (2014), pemanfaatan teknologi dalam pendidikan yang saat ini sedang berkembang seperti Augmented Realiy. Namun, pemanfaatan teknologi ini banyak mengalami beberapa rintangan. Hal tersebut menjadikan teknologi sebagai sebuah tantangan besar bagi sistem pendidikan (Konstantinos et al., 2013).

Pendidikan merupakan hal yang sangat berperan penting dalam kesuksesan suatu bangsa. Pendidikan yang baik akan membawa bangsa kepada kebaikan dimasa depan.
Terobosan dalam pendidikan khususnya dalam teknologi pembelajaran sangat diperlukan untuk mencapai hal tersebut.

Pembelajaran merupakan kegiatan guru secara terprogram dalam desain instruksional, untuk membuat belajar secara aktif, yang menekankan pada penyediaan sumber belajar (Sagala, 2010). Pembelajaran merupakan gabungan dari berbagai konsep mengajar dan konsep belajar (Kristiono et al., 2019). Pembelajaran yang ideal adalah dimana proses belajar mengajar yang dilakukan secara dua arah, dari pengajar dan peserta didik. Peserta didik tidak hanya diberikan ilmu secara searah saja, tetapi harus diberi stimulan atau rangsangan sehingga proses pembelajaran memberikan output yang lebih efektif. Dalam pembelajaran, objek yang berperan penting yaitu penggunaan media pembelajaran.

Media pembelajaran merupakan salah satu unsur yang memegang peran penting dalam suatu proses pembelajaran. Penggunaan media pembelajaran dapat mewakili apa yang kurang mampu guru ucapkan 
melalui kata-kata, sehingga

diproyeksikan menggunakan alat keabstrakan bahan dapat elektronik. Kelebihan metode dikonkretkan dengan kehadiran Augmented Reality yaitu dapat media pembelajaran (Rasyid et al., 2016). Penggunaan media pembelajaran dalam kegiatan belajar mengajar sangat membantu memperjelas penyampaian informasi maupun pesan (Arsyad, 2013). Media pembelajaran pada saat ini sangat dipengaruhi dengan kemajuan teknologi. Penerapan teknologi yang digunakan dalam proses pembelajaran memungkinkan untuk mempermudah peserta didik dalam memahami suatu proses pembelajaran. Salah satu teknologi yang sedang berkembang saat ini yaitu Augmented Reality.

Augmented Reality merupakan 'aya ke dalam sebuah dunia nyata. Menurut (Prasetiyo et al., 2018), Augmented Reality merupakan obyek virtual yang mampu menyampaikan informasi sehingga dapat membantu manusia dalam melakukan pekerjaannya sehari-hari. Novitasari (2019) mengemukakan bahwa Augmented Reality merupakan teknologi yang menggabungkan dunia maya dan dunia nyata dan menampilan visual yang lebih menarik dengan objek tiga dimensi yang seakan ada pada lingkungan yang nyata. Teknologi Augmented Reality dapat meanampilkan objek animasi dalam bentuk tiga dimensi beserta audio dari suatu materi (Pramono, 2018). Metode Augmented Reality juga memiliki kelebihan dari sisi interaktif karena menggunakan marker untuk menampilkan objek tiga dimensi tertentu yang di arahkan ke kamera. Selain itu penerapan konsep yang digunakan dapat meningkatkan daya nalar serta daya imajinasi peserta didik.

Perpaduan dunia virtual atau dunia maya dan dunia nyata ini diharapkan bisa membawa sebuah proses pembelajaran yang lebih efektif dan efisien dalam proses pembelajaran. Media pembelajaran yang menggunakan teknologi Augmented Reality dapat meningkatkan pemahaman siswa karena objek tiga dimensi, teks, gambar, video, maupun audio dapat 
ditampilkan pada waktu yang sama secara langsung (Abdoli-Sejzi, 2015). Menurut Salawati \& Indrawati (2015), siswa akan lebih mudah memahami suatu pelajaran jika didalamnya terdapat gambar animasi yang dapat menimbulkan kreatifitas siswa.

\section{PEMBAHASAN}

Teknologi Augmented Reality pada

\section{Pembelajaran}

Augmented Reality merupakan teknologi yang memproyeksikan benda maya ke dalam sebuah dnia nyata. Kelebihan metode Augmented Reality yaitu dapat menampilan visual yang lebih menarik dengan objek tiga dimensi yang seakan ada pada lingkungan yang nyata. Sistem Augmented Reality secara sederhana memiliki cara kerja sebagai berikut: kamera dari smartphone akan mendeteksi suatu objek marker atau penanda yang telah disediakan, kemudian kamera akan mengenali dan menandai pola marker tersebut lalu membandingkannya dengan database yang dimiliki. Bila database sesuai maka informasi yang ada pada marker tersebut akan ditampilkan sebagai objek tiga dimensi atau animasi sesuai yang telah dibuat sebelumya.

Metode Augmented Reality ini memiliki kelebihan dari sisi interaktif karena menggunakan marker untuk menampilkan objek tiga dimensi tertentu yang di arahkan ke kamera. Objek tiga dimensi tersebut akan menampilkan interface yang menarik dan mendekati bentuk yang sesungguhnya. Selain itu penerapan konsep yang digunakan dapat meningkatkan daya nalar serta daya imajinasi peserta didik.

Penggunaan Augmented Reality pada pembelajaran berkembang sangat pesat. Barrow (2019) dalam penelitian menunjukkan sebuah grafik bagaimana tren penggunaan Augmented Reality pada pembelajaran dengan perbadingan yaitu teknologi Virtual Reality. 


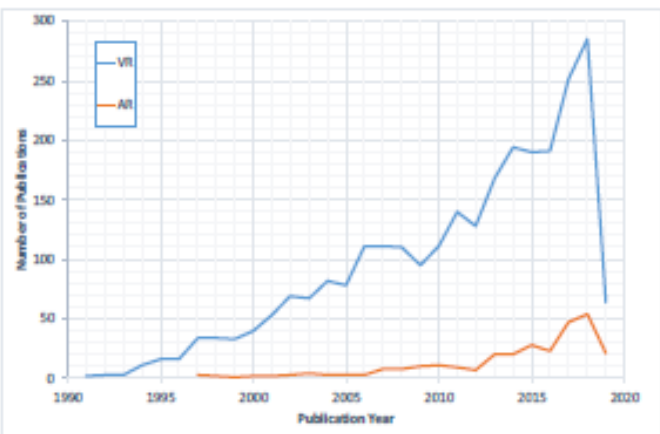

Gambar 1. Hasil publikasi Augmented Reality dan Virtual Reality (Sumber:

Barrow:2019)

Dari grafik tersebut dapat dilihat hingga tahun 2019 pertumbuhan Virtual Reality maupun Augmented Reality terus meningkat. Di Indonesia sendiri penggunaan Augmented Reality pada pembelajaran sudah banyak diterapkan. Hal tersebut tidak lepas dari berbagai kelebihan dalam penggunaanya salah satunya dapat membuat ataupun merangsang imajinasi peserta didik dalam memahami suatu materi pembelajaran. Terlebih siswa pada jenjang sekolah menengah atas dimana mereka cenderung untuk memiliki penafsiran atau imajinasi yang berbeda-beda antar individu. Penafsiran yang tersebut bisa menghambat proses pembelajaran dikarenakan pemahaman yang berbeda dari berbagai siswa.
Augmented Reality diharapkan dapat membantu menyamakan pandangan siswa dalam memahami suatu pembelajaran dengan memproyeksikan materi yang dianggap abstrak dipahami menjadi bentuk maya di dunia nyata.

Penggunaan Augmented Reality di Sekolah Menengah Atas

Dalam perkembangannya, Augmented Reality banyak dijadikan bahan penelitian oleh sebagian besar para peneliti di Indonesia. Hal tersebut sangar wajar mengingat teknologi akan dikupas habis kegunaannya untuk mempermudah pekerjaan manusia termasuk dalam dunia pendidikan kita ini. Banyak penelitian-penelitian yang menggunakan Augmented Reality sebagai objek penelitiannya.

Augmented Reality dalam penggunaannya pada pembelajaran Siswa Menengah Atas di Indonesia sangat beragam. Menurut Gusmida dalam penelitiannya yaitu Augmented Reality pada materi teori kinetik gas telah berhasil dibangun. Penelitian tersebut menggunakan metode R\&D (Riset and Development) dengan menggunakan 
model perancangan media pembelajaran tipe ADDIE (analysis, design, development, implementation, serta evaluation) yang dipadukan dengan aplikasi android berbasi Augmented Reality. Penelitiaannya mengemukakan bahwa pengembangan media pembelajaran ini telah dinyatakan valid dengan kategori sangat tinggi, sehingga media pembelajaran ini layak digunakan sebagai media pembelajaran fisika untuk siswa kelas XI Sekolah Menengah Atas.

Penggunaan Augmented Reality dalam pembelajaran Sekolah Menengah Atas dapat juga berupa aplikasi pada smartphone. Menurut Wahyudi, dalam papernya mengemukakan Dalam penererapan Augmented Reality untuk media pembelajaran terdapat beberapa hal yang perlu diperhatikan dalam penelitian selajutnya antara lain seperti kebutuhan penambahan animasi dan konten yang lebih interaktif pada objek tiga dimensi yang muncul dari halaman buku, kebutuhan integrasi dengan melibatkan pengajar dalam proses perancangan dan penggunaan serta memiliki dukungan komunikasi dengan mobile services agar dapat menghasilkan konten yang interaktif.

Menurutnya penggunaan Augmented Reality sebagai teknologi yang mampu mengembangkan buku tradisional menjadi buku interaktif, yang dapat mendukung proses pengenalan dan pembelajaran Candi Prambanan. Augmented Reality merupakan salah satu topik yang sangat baik untuk diterapkan pada media buku pembelajaran.

Paper tersebut juga memberikan inovasi baru pada pendidikan terutama buku pembelajaran sejarah. Beberapa kontribusi utama yang telah dilakukan penelitian tersebut antara lain (1) menerapkan teknik markerless serta menghadirkan teknik interaksi yang baru yaitu virtual button dengan meningkatkan interaktifitas dari buku Augmented Reality untuk pengembangan buku interaktif selanjutnya. mendiskusikan Augmented Reality sebagai teknologi yang mampu meningkatkan kualitas software untuk edukasi. Khususnya untuk mempelajari budaya Indonesia. 
Penelitian lain yang senada yaitu penelitian Sugih menjadikan Augmented Reality sebagai media pembelajaran mata pelajaran Kimia berbasis android pada siswa sekolah menengah atas. Penelitian tersebut memanfaatkan Augmented Reality sebagai media pembelajaran interaktif untuk meningkatkan siswa dalam memahami informasi berkaitan dengan bentuk molekul senyawa serta turunannya. Hasil dari penelitiannya menunjukkan bahwa siswa merasa dipermudah dalam memahami bentuk molekul serta senyawa benzena dan turunannya menggunakan aplikasi berbasis Augmented Reality.

Rajmah (2017) dalam penelitiannya yang juga menggunakan Augmented Reality sebagai media pembelajaran untuk mata pelajaran Kimia menjelaskan bahwa sejatinya teknologi Augmented Reality tedapat tiga karakteristik yang menjadi dasar dari teknologi Augmented Reality yaitu (1) kombinasi dunia nyata dengan dunia maya (virtual), (2) interaksi yang ada berjalan secara langsung atau real-time, serta, (3) bentuk data kontekstual dalam teknologi Augmented Reality dapat berupa data lokasi, data audio, data video, maupun dalam bentuk data model tigas dimensi.

Penelitian mengenai Augmented Reality terhadap media pembelajaran Kimia di sekolah menengah atas juga dilakukan oleh Hafidha (2014). Penelitian tersebut membahas teknologi Augmented Reality sebagai media pembelajaran dari sistem periodik unsur kimia yang dikemas menjadi suatu aplikasi dengan menampilkan objek tiga dimensi secara virtual. Hasil penelitiannya membuktikan bahwa responden yang tidak lain adalah siswa disini sebanyak $80 \%$ menyatakan sangat baik dan setuju. Hal tersebut yang membuat penelitian Augmented Reality sebagai media pembelajaran sangat diterima baik oleh siswa, terlebih disini siswa sekolah menengah atas.

$\begin{array}{rrr}\text { Berbeda } & \text { dari } & \text { penelitian } \\ \text { sebelumnya } & \text { yang } & \text { umumnya }\end{array}$
menggunakan teknologi Augmented Reality pada mata pelajaran kimia, Amir, (2017) dalam penelitiannya terhadap keefektifan buku ajar dan 
Augmented Reality pada konsep sistem pencernaan di sekolah menengah atas. Penelitian ini menjelaskan bahwa pengembangan buku ajar dan Augmented Reality dapat mengurangi pemikiran yang abtrak dari materi pelajaran yang dipahami siswa, sehingga aplikasi Augmented Reality dapat meningkatkan proses belajar mengajar yang lebih aktif, interaktif. Penelitian ini menggunakan jenis penelitian R\&D (Riset and Development) dengan menggunakan model desain ADDIE yaitu analysis, design, development, implementation, serta evaluation. Hasil dari penelitian tersebut menyatakan dengan kategori valid sehingga buku ajar dan Augmented Reallity juga berkategori praktis. Hal tersebut didapat dari sebesar $88 \%$ siswa yang diteliti mampu mencapai nilai minimal ketuntasan belajar.

Penelitian lain mengenai pembelajaran menggunakan Augmented Reality pada penelitian yang dilakukan oleh Mauludin (2017). Penelitian tersebut menggunakan Augmented Reality sebagai media pembelajaran sistem pencernaan pada manusia. Penelitian tersebut menggunakan metode Pre Test dan Post Test . Hasil dari penelitian tersebut menunjukkan peningkatan pada hasil belajar menggunakan teknologi Augmented Reality sehingga dapat diambil kesimpulan bahwa teknologi Augmented Reality dapat diterapkan sebagai media pembalajaran sistem pencernaan manusia pada proses belajar mengajar.

Penelitian yang dilakukan oleh Nurdiyanti (2017) mengemukakan bahwa teknologi Augmented Reality dalam hal pedagogis dapat menjelaskan konsep sistem ekskresi manusia secara efektif sehingga membantu guru dan siswa dalam pembelajaran. Siswa dapat terbantu memahami konsep dengan baik, serta guru dapat terbantu untuk mencapai tujuan pembelajarannya dengan baik. Penelitian ini lebih menonjolkan efisiensi pembelajaran sehingga mempermudah guru dalam menjelaskan pembeljarannya.

Haryanto (2017) dalam penelitiannya menggunakan Augmented Reality sebagai media pembelajaran materi pembelahan sel 
dalam mata pelajaran biologi. Augmented Reality diatanamkan pada marker yang ada pada buku pelajaran biologi siswa. Penelitian yang menggunakan metode Pres Test dan Post Test mengemukakan bahwa penggunaan Augmented Reality pada media pembelajaran tidak hanya menampilkan visual saja, akan tetapi teknologi Augmented Reality juga dapat menampilkan audio sehingga Augmented Reality dapat membantu siswa dalam belajar memahami materi dengan lebih luas dan efisien.

$$
\text { Meslilesi (2017) dalam }
$$
penelitiaanya juga menggunakan Augmented Reality sebagai media pembelajaran virus dalam mata pelajaran biologi. Penelitian tersebut menggunakan buku mata pelajaran yang sudah diberi marker atau penanda yang kemudian penanda tersebut dipindah oleh smartphone. Penelitian ini lebih menekankan kepada kompatibilitas penggunaan aplikasi Augmented Reallity pada smartphone dengan berbagai macam sistem operasi android yang berbeda. Hasilnya dikemukakan bahwa smartphone dapat menampilkan marker yang ada mulai dari android versi 4.4 (KitKat) hingga $\quad 6.0 .1$ (Marhmallow).

Hampir serupa dengan penelitian sebelumnya, Romadhon (2017) dalam penelitian yang membahas penerapan Augmented Reallity berbasis android yang digunakan sebagai media pembelajaran sel penyusun jaringan pada sistem gerak. Perbedaanya, penelitian yang dilakukan sebelumnya lebih kearah kompatibilitas perangkat yang digunakan, sedangkan penelitian ini lebih kepada pengujian marker, apakah marker yang telah ditandai ataupun dibuat bisa ditampilkan apa tidak. Hasil dari penelitian tersebut menjelaskan bahwa dari 14 marker yang ada, ada 10 marker yang dapat ditampilkan secara optimal.

Melihat dari penelitian yang dilakukan oleh beberapa peneliti yang sudah dijelaskan sebelumnya, salah satu faktor yang mempengaruhi penggunaan Augmented Reallity apakah berhasil atau tidak yaitu pada perangkat smartphone yang dipakai apakah memadai atau tidak serta kepada marker yang diberikan, apakah marker tersebut dapat terbaca oleh pemindai kamera smartphone 
atau tidak. Marker tidak hanya dapat digunakan atau diterapkan pada buku mata pelajaran saja, akan tetapi masih banyak cara lain untuk menempatkan marker tersebut.

Penelitian yang menggunakan objek selain buku mata pelajaran dalam pengaplikasian Augmented Reallity salah satunya dilakukan oleh Efendi (2018) yang menggunakan media pembelajaran berbasis Augmented Reality Card untuk mengenal candicandi pada masa kerajaan Singhasari. Marker atau penanda yang kemudian dipindah diletakkan pada sebuah card yang mana lebih praktis dan lebih efisien. Menurutnya meskipun hasil yang dicapai dalam penelitiannya menyatakan valid, akan tetapi masih banyak hal yang harus diperbaiki dan disempurnakan. Media pembelajaran yang dikembangkan memiliki keunggulan serta kelemahan. Keunggulan tersebut meliputi (1) media pembelajaran tersebut dianggap mampu meningkatkan minat peserta didik dalam belajar sejarah, (2) media pembelajaran tersebut dapat dijadikan wadah untuk menambah wawasan ilmu pengetahuan agar lebih maksimal, (3) media pembelajaran tersebut dapat membantu siswa dalam belajar mengenai peninggalan kerajaan Singhasari dengan lebih efisien, (4) desain media pembelajaran tersebut mengikuti perkembangan zaman, serta (5) memiliki objek tiga dimensi yang dapat membantu siswa dalam mencapai tujuan belajar. Selain mengemukakan beberapa kelebihan dari hasil penelitiannya, beliau juga mengemukakan beberapa kelemahan dalam media pembelajaran tersebut. Berikut kelemahanan yaitu : (1) media pembelajaran tersebut memakan ruang penyimpanan yang cukup besar pada smartphone yang digunakan siswa, (2) pertanyaan dalam media pembelajaran masih terbatas, (3) materi pembelajaran hanya berfokus pada kartu (card) saja

Disamping kelebihan dan kelemahan media pembelajaran berbasis Augmented Reality yang dikemukakan Efendi (2018) dalam penelitiaanya, beliau juga mengatakan bahwa proses belajar mengajar harus diawasi oleh guru dalam artian disini penggunaan 
smartphone. Penggunaan

smartphone tersebut harus benarbenar dioptimalkan jangan sampai membuat siswa membuang waktu dengan membuka konten lain ataupun sekedar bermain dengan smartphone.

Melihat dari beberapa penelitian diatas, penggunaan Augmented Reality memang kebanyakan memanfaatkan smartphone android. Penggunaan smartphone memang memudahkan selain bentuknya yang mudah dibawa kemana saja, hal lain nya yaitu jika melihat dari keadaan sekarang dimana hampir semua siswa mulai dari jenjang sekolah dasar hingga sekolah menengah atas memiliki smartphone. Akan tetapi smartphone ibarat pisau bermata dua, jika dapat dimanfaatkan dengan semaksimal mungkin akan membawa suatu hasil yang baik, akan tetapi apabila dalam penggunaanya hanya untuk hal-hal negatif maka dampaknya jauh akan lebih buruk. Disinilah peran orang tua serta guru sangat diperlukan dalam pengawasan penggunaan smartphone pada anak.

Selain dampak dari Augmented Reality dengan smartphone, nyatanya penggunaan teknologi tersebut masih sangat minim digunakan di hampir seluruh sekolah menengah atas di Indonesia. Salah satu faktor yang menyebabkannya ialah umumnya masih banyak sekolah yang tidak mengizinkan siswanya membawa smartphone ke sekolah. Sehingga hal tersebut dapat menjadi salah satu bahan evaluasi dalam penerapan media pembelajaran berbasis Augmented Reality.

Penelitian oleh Dalim (2017) mengemukakan bahwa teknologi Augmented Reality telah matang sampai pada titik dimana dapat diterapkan pada banyak hal dan juga jangkauan yang lebih luas dari hanya sebuah aplikasi. Penelitian tersebut juga mengemukakan bahwa pengalaman pendidikan yang ditawarkan oleh Augmented Reality berbeda karena sejumlah alasan, diantaranya yaitu : (1) dukungan interaksi tanpa batas antara lingkungan nyata dengan lingkungan maya (virtual), (2) penggunaan metafora antarmuka yang nyata untuk manipulasi tampilan suatu objek, (3) kemampuan untuk 
bertransisi dengan lancar antara realitas (nyata) dengan virtualitas (maya).

Beliau juga mengemukakan bahwa mengintegrasikan Augmented Reality dalam pendidikan dapat membuat pendidikan lebih cerah di masa depan. Augmented Reality berpotensi melibatkan siswa dalam pengalaman belajar yang lebih baik. Penelitian tersebut juga menjaskan ada beberapa faktor yang mempengaruhi penerimaan Augmented Reality dalam pendidikan. Faktor tersebut seperti : (1) kurikulum meliputi aspek teknis teknologi seharusnya diseimbangkan dengan aspek pedagogis dari suatu isi pendidikan, (2) stabilitas interaksi dimana didalamnya terkait kendalan aplikasi Augmented Reality untuk menyediakan keterlibataan yang berkelanjutan selama interaksi, (3) kemampuan belajar mandiri, interaksi dalam Augmented Reality dapat dilakukan sendiri tanpa perlu guru atau bimbingan orang tua, (4) keterlibatan orang tua di setiap titik atau bentuk penggunaan teknologi, (5) latar belakang siswa, (6) alat atau perangkat yang digunakan untuk menyebarkan Augmented Reality.

Penelitian lain yang dilakukan oleh Utomo (2017) dengan memanfaatkan Augmented Reality sebagai pemilihan alat dalam laboratorium sekolah. Penelitian ini mengukur sebagaimana efektifitas penggunaan teknologi Augmented Reality pada laboratorium sekolah menengah atas. Penelitian tersebut juga menjadi terobosan bagi pembelajaran di sekolah menengah atas dimana pemanfaatan teknologi harus sudah diberdayakan.

Penelitian Barrow (2019) terkait penggunaan Augmented Reality menyatakan bahwa ada beberapa kelebihan pembelajaran menggunakan Augmented Reality, yaitu dimana pengguna dalam artian disini bahwa siswa dapat mengeksplor konten yang ada di lingkungan dunia nyata dan berinteraksi dengan konten tersebut. Selain itu, penggunaan Augmented Reality juga memungkinkan terjadinya pembelajaran kelompok yang lebih efektif dimana Augmented Reality dapat dinikmati secara bersama serta penggunaan 
Augmented Reality dapat melakukannya serta aktif terlibat

dikombinasikan dengan bentuk

pembelajaran lain sehingga

memungkinkan pembelajaran

kolaboratif, dan memberikan peningkatan ruang lingkup untuk menghidupkan pembelajaran dengan cara yang berbeda.

Saidin (2015) menjelaskan dalam penelitiaanya bahwa tinjauan penelitian yang dilakukan dibeberapa bidang dalam pendidikan menunjukkan bahwa teknologi Augmented Reality memliki potensi untuk dikembangkan lebih lanjut. Ini terjadi karena kelebihan dan kekurangan teknologi Augmented Reality yang bermanfaat untuk melibatkan siswa dalam proses pembelajaran dan membantu mereka meningkatkan keterampilan visualisasi. Fitur yang terdapat di Augmented Reality juga membantu guru dalam menjelaskan dengan baik serta membuat siswa mudah memahami apa yang diajarkan. Penggunaan teknologi Augmented Reality juga telah menerima respon yang baik dari siswa. Respon yang baik ini sangat penting karena menunjukkan kesediaan siswa untuk dalam pembelajaran.

Meskipun teknologi Augmented Reality tergolong masih baru dalam pendidikan, akan tetapi seiring berjalan waktu hal tersebut dapat dibenahi segala kekurangannya sehingga potensi teknologi Augmented Reality dapat dieksplorasi lebih penuh. Fungsi menguntungkan Augmented Reality dapat digunakan secara luas disemua bidang pendidikan untuk menciptakan efisiensi pengajaran dan pembelajaran.

Teknologi Augmented Reality juga dapat dimanfaatkan sebagai alat peraga suatu pembelajaran. Bachtiar \& Haryanto (2015) dalam penelitiaannya menggunakan Augmented Reality sebagai media atau alat peraga organ tubuh manusia pada sekolah menengah atas. Hasil dari penelitian tersebut mengemukakan bahwa alat peraga secara virtual sangat dibutuhkan sebagai penunjang pembelajaran. Aplikasi Augmented Reality mampu menampilkan detail objek tigas dimensi secara detail sehingga membantu siswa untuk lebih 
memahami tentang kegunaan organ dalam manusia. Augmented Reality membuat siswa mendapatkan pengalaman serta pengetahuan tambahan mengeanai perkembangan teknologi.

Penelitian lain terkait Augmented Reality dari Joan (2015) mengemukakan bahwa teknologi Augmented Reality sangat menjanjikan sebagai alat untuk menstimulus belajar yang lebih efektif. Teknologi Augmented Reality dapat melengkapi buku teks ataupun modul laiinya sehingga menghasilkan tambahan informasi kepada siswa. Augmented Reality membantu siswa dalam memahami mata pelajaran dengan membiarkan mereka memvisualkan konsep dan berinteraksi dengan model virtual yang ada. Teknologi Augmented Reality juga memungkinkan pembelajaran melalui kolaborasi jarak jauh, dimana siswa dan guru tidak hadir dalam waktu yang sama dan dapat berbagi pembelajaran dengan memanfaatkan virtual teknologi yang ada. Selain hal tersebut, Augmented Reality juga masih banyak masalah terkait teknologi yang harus diperbaiki sebelum dapat menjadi komponen dalam suatu pendidikan.

\section{KESIMPULAN}

Berdasarkan hasil telaah dari berbagai penelitian yang telah dilakukan tersebut dapat diambil kesimpulan bahwa penggunaan Augmented Reality dalam pendidikan sekolah menengah atas di Indonesia sangat beragam. Augmented Reality dirasa sangat mumpuni dalam memenuhi kebutuhan dunia pendidikan pada era saat ini. Penggunaan Augmented Reality sangat membantu siswa dalam meraih keberhasilan proses belajar. Augmented Reality juga sangat membantu guru dalam menyampaikan pembelajarannya dengan lebih efektif.

Penggunaan Augmented Reality dalam pendidikan memang sangat membantu proses pembelajaran yang ada, akan tetapi ada beberapa hal yang penulis rasa untuk dilakukan kajian lebih dalam lagi. Penulis memberikan saran untuk penelitian selanjutnya agar selain mengetahui penggunaan Augmented Reality 
dalam pendidikan beserta

\section{DAFTAR RUJUKAN}

kegunaannya, penulis berharap pada penelitian selanjutnya agar juga memahami kelemahan penggunaan Augmented Reality pada pendidikan terlebih di Indonesia, mengingat negara kita negara yang luas sehingga pendidikan belum sepenuhnya dirasa merata. Penggunaan Augmented Reality dikhawatirkan tidak mempermudah dalam penyampaian proses pembelajaran, akan tetapi malah membuat sulit proses pembelajaran ketika tidak ditangani dengan SDM yang tepat.

\section{UCAPAN TERIMA KASIH}

Ucapan terima kasih saya

sampaikan kepada para peneliti yang telah saya jadikan rujukan dalam penulisan artikel telaah ini, serta kepada dosen pembimbing, Bapak Ence Surahman, S.Pd., M.Pd dan Ibu Susilaningsih M.Pd yang telah membimbing dalam penulisan artikel telaah ini. Semoga artikel telaah ini dapat bermanfaat bagi masyarakat umum.

Abdoli-Sejzi, A. (2015). Augmented Reality And Virtual Learning Environment. Journal Of Applied Sciences Research, $11(8), 1-5$.

Amir, I. (2017). Pengembangan Buku Ajar Dan Augmented Reality Pada Konsep Sistem Pencernaan Di Sekolah Menengah Atas. Pascasarjana.

Arsyad, A. (2013). Media Pembelajaran; Edisi Revisi.

Bachtiar, M. Y., \& Haryanto, H. (2015). Perancangan Aplikasi Berbasis Markerless Augmented Reality Untuk Alat Peraga Organ Dalam Manusia Pada Sekolah Menengah Atas. Seminar Nasional Teknologi Informasi Dan Komunikasi Terapan (SEMANTIK), 63-66. Barrow, J., Forker, C., Sands, A., O'Hare, D., \& Hurst, W. (2019). Augmented Reality For Enhancing Life Science Education. VISUAL 2019-The Fourth International Conference

On Applications And Systems

Of Visual Paradigms, 1(1), 1-7.

Dalim, C. S. C., Kolivand, H., 
Kadhim, H., Sunar, M. S., \&

Billinghurst, M. (2017). Factors

Influencing The Acceptance Of

Augmented Reality In

Education: A Review of The

Literature. Journal Of Computer

Science, 13(11), 581-589.

Https://Doi.Org/10.3844/Jcssp.2

017.581 .589

Efendi, M. Y., Lutfi, I., Utami, I. W.

P., \& Jati, S. S. P. (2018).

Pengembangan

Media

Pembelajaran

Sejarah

Augmented Reality Card (Arc)

Candi-Candi Masa Singhasari

Berbasis Unity3D Pada Pokok

Materi Peninggalan Kerajaan

Singhasari Untuk Peserta Didik

Kelas X KPR1 SMK Negeri 11

Malang. Jurnal Pendidikan

Sejarah Indonesia, 1(2), 176187.

Https://Doi.Org/10.17977/Um0

33v1i22018p176

Gusmida, R., Rahmad, M., Islami, N., Education, P., \& Program,

S. (N.D.). Development Of Physics Learning Media Using Augmented Reality In Gas

Kinetic Theory For. 1-12.

Hafidha, P. N. W. (2014).
Augmented Reality Sistem

Periodik Unsur Kimia Sebagai

Media Pembelajaran Bagi Siswa

Tingkat SMA Berbasis Android

Mobile.

Universitas

Muhammadiyah Surakarta.

Haryanto, T., Anra, H., \& Pratiwi, H.

S. (2017). Aplikasi Augmented

Reality Sebagai Media

Pembelajaran Materi

Pembelahan Sel Dalam Mata

Pelajaran Biologi. JUSTIN

(Jurnal Sistem Dan Teknologi Informasi), 5(2), 164-168.

Hidayat, T. (2014). Penerapan

Teknologi Augmented Reality Sebagai Model Media Edukasi

Kesehatan Gigi Bagi Anak.

Creative Information

Technology Journal, 2(1), 7792.

Joan, D. R. R. (2015). Articles Enhancing Education Through Mobile By. I-Manager's Journal Of Educational Technology, 11(4), 8-15.

Konstantinos, T., Andreas, A., \& Karakiza, T. (2013). Views Of ICT Teachers About The Introduction Of ICT In Primary Education In Greece. Turkish 
Online Journal Of Educational Technology-TOJET, 12(1), 200-209.

Kristiono, I. D., Dwiyogo, W. D., \& Hariadi, I. (2019). Pembelajaran Ilmu Gizi Olahraga Berbasis Blended Learning Pada Mahasiswa Pendidikan Jasmani, Kesehatan, Dan Rekreasi. Jurnal Pendidikan: Teori, Penelitian, Dan Pengembangan, 4(2), 235241.

Mauludin, R., Sukamto, A. S., \& Muhardi, H. (2017). Penerapan Augmented Reality Sebagai Media Pembelajaran Sistem Pencernaan Pada Manusia Dalam Mata Pelajaran Biologi. JEPIN (Jurnal Edukasi Dan Penelitian Informatika), 3(2), 117-123.

Meslilesi, M. I., Anra, H., \& Pratiwi,

H. S. (2017). Penerapan Augmented Reality Sebagai Media Pembelajaran Virus

Dalam Mata Pelajaran Biologi Kelas X SMA (Studi Kasus: SMA Negeri 7 Pontianak). JUSTIN (Jurnal Sistem Dan Teknologi Informasi), 5(2), 8084.
Novitasari, A. L. (2019). Aplikasi Pengenalan Senjata Tradisional Indonesia Menggunakan Augmented Reality Berbasis Android. Institut Teknologi Nasional Malang.

Nurdiyanti, $\quad \mathrm{N}$. (2017).

Pengembangan Buku Ajar Dan Augmented Reality Pada Konsep Sistem Ekskresi Di Sekolah Menengah Atas. Pascasarjana.

Pramono, H. D. (2018). Penerapan Teknologi Augmented Reality Pada Game Pengenalan Hewan Berdasarkan Jenis Makanannya Berbasis Mobile. J-INTECH, 6(01), 166-172.

Prasetiyo, T. K., Setyosari, P., \&

Sihkabuden, S. (2018).

Pengembangan Media

Augmented Reality Untuk

Program Keahlian Teknik

Gambar Bangunan Di Sekolah Menengah Kejuruan. JINOTEP (Jurnal Inovasi Dan Teknologi Pembelajaran): Kajian Dan Riset Dalam Teknologi Pembelajaran, 4(1), 37-46. Rajmah, M. A.-G., Adrian, M., \& Sanjaya, M. B. (2017). Aplikasi 
Alchemist Menggunakan

Augmented Reality Berbasis

Android Untuk Pembelajaran

Kimia Sma. Eproceedings Of

Applied Science, 3(3).

Rasyid, M., Azis, A., \& Saleh, A. (2016). Pengembangan Media

Pembelajaran Berbasis

Multimedia Dalam Konsep

Sistem Indera Pada Siswa Kelas

Xi Sma. Jurnal Pendidikan

Biologi, 7(2), 69-80.

Https://Doi.Org/10.17977/Jpb.V

$7 \mathrm{i} 2.722$

Romadhon, E. N., Anra, H., \&

Pratiwi, H. S. (2017). Penerapan

Augmented Reality Berbasis

Android Sebagai Media

Pembelajaran Sel Penyusun

Jaringan Pada Sistem Gerak

Dalam Mata Pelajaran Biologi

(Studi Kasus: SMA Negeri 7

Pontianak). JUSTIN (Jurnal

Sistem Dan Teknologi

Informasi), 5(2), 89-92.

Sagala, S. (2010). Konsep Dan

Makna Pembelajaran. Bandung:

Alfabeta.

Saidin, N. F., Halim, N. D. A., \& Yahaya, N. (2015). A Review

Of Research On Augmented
Reality In Education:

Advantages And Applications.

International Education Studies, 8(13), 1-8.

Https://Doi.Org/10.5539/Ies.V8

$\mathrm{n} 13 \mathrm{p} 1$

Salawati, T., \& Indrawati, N. D. (2015). Tahap Analisis Untuk Pengembangan "ASETARO"

Komik Pendidikan Kesehatan

Untuk Anak Tentang Bahaya

Merokok.

PROSIDING

SEMINAR NASIONAL \& INTERNASIONAL.

Saputri, D. S. C. (2017). Penggunaan

Augmented Reality Untuk

Meningkatkan Penguasaan

Kosa Kata Dan Hasil Belajar.

Jutisi: Jurnal Ilmiah Teknik

Informatika Dan Sistem

Informasi, 6(1), 1357-1366.

Sugih, A., Suryo, P., Wibowo, A., \& Orisa, M. T. M. (N.D.). Augmented Reality Senyawa Kimia Sebagai Media Pembelajaran Bagi Siswa Sma. 1-8.

Utomo, D. S., Arwani, I., \& Wardhono, W. S. (2017). Implementasi Mobile Augmented Reality Pada 
Aplikasi Pemilihan Sarana Dan

Prasarana Laboratorium

Sekolah Menengah Atas. Jurnal

Pengembangan Teknologi

Informasi Dan Ilmu Komputer

E-ISSN, 2548, 964X.
Wahyudi, A. K. (N.D.). Arca , Pengembangan Buku Interaktif Berbasis Augmented Reality Dengan Smartphone Android. 3(2), 96-102. 